[20] Kriukova, A., Vladymyrova, I. (2018). Determination Of Technological Parameters And Indicators Of The Quality Of New Herbal Collection. EUREKA: Health Sciences, 6, 61-68. doi: http://doi.org/10.21303/2504-5679.2018.00801

[21] Vyshnevska, L. I., Shmalko, O. O., Soldatov, D. P. (2019). Study on the development of multicomponent dry uroholum extract and its pharmaco-technological indicators. Management, Economics and Quality Assurance in Pharmacy, 2 (58), 16-21. doi: http://doi.org/10.24959/uekj.19.19

[22] Yanickaya, A. V., Mitrofanova, I. Yu., Heilik, Yu. V. (2014). Optimizaciya processa ekstragirovaniya flavonoidov iz travy melkolepestnika kanadskogo. Vestnik Volgogradskogo gosudarstvennogo medicinskogo universiteta, 2 (50), 20-23.

[23] Kutateladze, G. R., Fedoseeva, L. M. (2019). Research in the Development and Validation of the Method of Quantitative Determination of Flavonoids in the Common Sorrel Herba, Gathered in the Altai Territory. Drug development \& registration, 8 (2), 80-86. doi: http://doi.org/10.33380/2305-2066-2019-8-2-80-86

\title{
MARKETING ANALYSIS OF THE ASSORTMENT OF DRUGS FOR THE TREATMENT OF HERPES VIRAL DISEASES AT THE PHARMACEUTICAL MARKET OF UKRAINE
}

\author{
Lydmila Kienko ${ }^{1}$ \\ kienko.pharm@gmail.com \\ Vita Hrytsenko ${ }^{1}$ \\ nika.gritsenko@gmail.com \\ Larysa Iakovlieva \\ Department of Pharmacoeconomics ${ }^{2}$ \\ iakovlievalv@gmail.com \\ Larysa Bobrytska \\ lora2015dm@gmail.com \\ ${ }^{1}$ Department of Industrial Technology of Drugs \\ ${ }^{2}$ National University of Pharmacy \\ 53 Pushkinska str., Kharkiv, Ukraine, 61002
}

\footnotetext{
Abstract

Nowadays there is a tendency towards the spread of viral diseases that cause significant complications to human health. Therefore, the question of creating new drugs that have a high antiviral effect is topical.

The aim. To study the range of drugs in Ukraine for the treatment of herpes viral diseases.

Materials and methods. In the work were used the list of drugs from official sources of information, which were processed by methods of generalization, systematization, graphic, comparative and structural analysis.

Results and discussion. The marketing research of drugs for the treatment of herpes viral diseases presented at the pharmaceutical market of Ukraine has been conducted. According to the results it is found that 80 drugs for the treatment of herpes viral diseases of various dosage forms are presented in the domestic market, of which $70 \%$ - tablets; $51 \%$ - medicines produced by the industry of Ukraine; $94 \%$ - are monocomponent preparations.

Soft drugs play important role in the treatment of skin diseases because they provide a direct effect of the drugs on the pathogens, eliminate inflammatory phenomena and eliminate or reduce the symptoms of the disease. Soft dosage drugs have practically no contraindications, they can be used at any age, regardless of the presence of comorbidities.
} 
Conclusions. Domestic drugs (51\% of the total range) dominate in the market structure. The main part (94\%) consist of monocomponent preparations. The results of the research prove the relevance of the development of new combined soft dosage forms for the treatment of herpes viral diseases, which should be produced by the Ukrainian industry and satisfy the medical and economical needs of patients. The results of the marketing analysis show that it is relevant and promising to create new combined the soft dosage forms for the treatment of herpes viral diseases.

Keywords: pharmaceutical market, herpes viral diseases, assortment analysis, soft dosage forms.

DOI: $10.21303 / 2504-5679.2020 .001285$

\section{Introduction}

Herpes viral diseases are among the most common diseases in the world, which is a leading medical and social problem $[1,2]$. According to the WHO studies, about $80-90 \%$ of the world's population are infected with one or more types of herpes virus [3, 4]. The number of patients with herpes viral infections annually increases by $10 \%[5,6]$. In Europe, the third of the population is suffering from herpes viral diseases $[7,8]$.

Due to the immunosuppressive effect of herpes viruses, the immune system is impaired, which gradually leads to chronic infection and possible damage to various organs and systems (eyes, liver, mucous membranes, skin, CNS), as well as the ability to replicate in all "host" cells (leukocytes, monocytes, fibroblasts) [9, 10]. Viruses are capable of triggering apoptosis - a genetic program of cell death that also contributes to the development of diseases of the internal organs [11].

Herpes diseases are more commonly manifested in skin lesions that occur around the mouth, nose and ears. Initially occurs itching, burning and pain. After 1-2 days, small, transparent vesicles appear in groups.On the 3rd-4th day the bubbles dry up, in their place crusts are formed, which after 5-7 days fall away. Sometimes the bubbles merge and then flake off to produce surface erosion, which gradually heals without changes in skin.

Skin lesions in herpes viral infection may be zosterroform, hemorrhagic, hemorrhagic-necrotic or ulcer-necrotic.

For the pharmacotherapy of viral infections, the following drugs are used: etiotropic, pathogenetic and symptomatic [12]. The etiotropic drugs include acyclic guanosine analogues, interferons and immunoglobulins. Leading place among the etiotropic approaches is antiviral therapy, represented by a large group of acyclic nucleoside analogues - acyclovir, valacyclovir, famciclovir, etc. Immunotherapy for herpes viral infections, which use interferon and immunoglobulin preparations, is an additional component of etiotropic therapy [13, 14].

Pathogenetic drugs for the treatment of herpes viral infections are represented by various pharmacological groups: immunomodulators, non-steroidal anti-inflammatory drugs, antihistamines, antiseptic drugs, multivitamin drugs. Non-steroidal anti-inflammatory drugs, adaptogens, and antioxidants include symptomatic drugs that affect concomitant symptoms $[15,16]$.

At the pharmaceutical market of Ukraine, drugs for the treatment of herpes viral diseases should present with a wide range and various dosage forms, which enable the doctor and the patient to choose the drug taking into the location of the lesion, the effectiveness and safety of the drug and the financial capacity of patient. Drugs for the treatment of herpes viral diseases in skin lesions should present with the soft dosage forms that are topical in the treatment of skin $[17,18]$.

Due to the large spread of herpes viral infections, their lifelong persistence in the human body, reactivation against the background of immunodeficiency and the development of various complications, creating of new drugs for the treatment of the above pathology remains relevant [19].

Therefore, it was important to research the segment of medicines for the treatment of herpes viral diseases at the pharmaceutical market of Ukraine and determine which dosage forms are available in most and which are limited.

The aim of the research. The aim of the work was to research of the segment of the drug market for the treatment of herpes viral diseases, presented at the pharmaceutical market of Ukraine 
in 2019, to substantiate the feasibility of creating and introducing new drugs into the range of manufacturing enterprise.

\section{Materials and methods}

The subjects of the study were selected registered drugs at the pharmaceutical market of Ukraine which use in the pharmacotherapy of herpes viral diseases. The study used data from the State Register of Medicines of Ukraine and data from the electronic directory - "CompendiumMedicines" [20]. During the study were applied methods of generalization, systematization, graphical, comparative and structural analysis. The data obtained are systematized and clearly presented in the diagrams with explanations and conclusions.

\section{Research results}

In the course of marketing research, a step-by-step analysis of the drugs used for the treatment of herpes viral diseases by dosage forms, countries of origin and a combination of active substances was carried out. The obtained data showed that in the domestic market in 2019, 80 names of medicines for the treatment of herpes viral diseases are presented. The analysis of the assortment of these drugs by the forms of issue are presented in Fig. 1.

As can be seen from the figure, the most common dosage form are tablets $(70 \%)$. Also at the pharmaceutical market of Ukraine are available syrups (11\%), powders and capsules $4 \%$ each, drops ( $2 \%$ ), lyophilisate for solution for infusions (1\%). The proportion of the soft dosage forms in the study group is $8 \%$, namely in the form of cream $-6 \%$, ointments $-2 \%$.

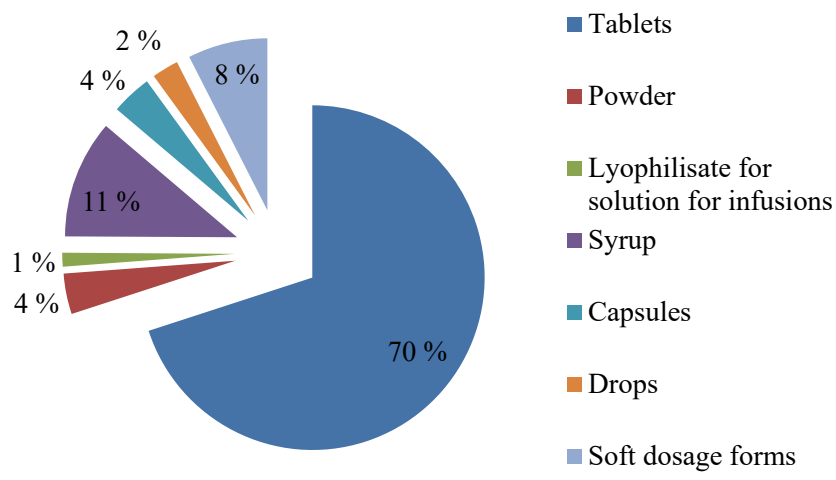

Fig. 1. Propositions of dosage forms of drugs for the treatment of herpes viral diseases

The next stage of the researching was the study of drugs by producing countries. The distribution of drugs is shown in Fig. 2.

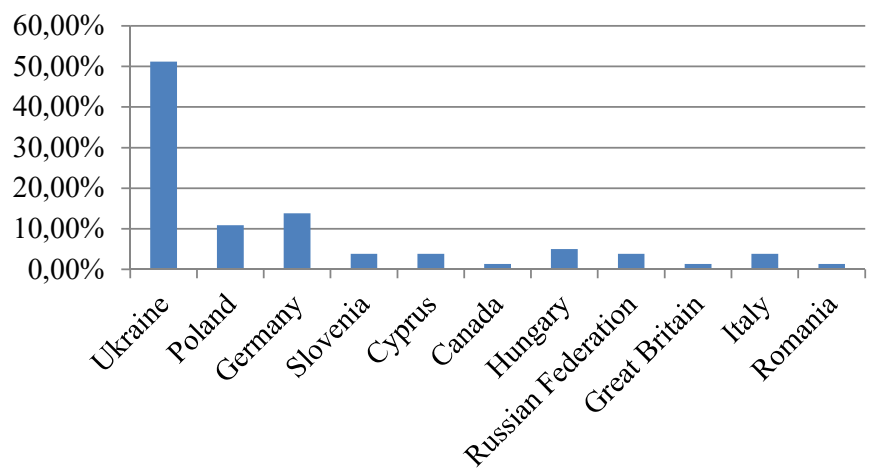

Fig. 2. The diagram of the ratio of drugs for the treatment of herpes viral diseases on the manufacturing country 
It is established that by number of drugs the first place belongs to Ukraine (51\%). Offers to the pharmaceutical market also come from Germany (14\%), Poland (11\%). Assortment of drugs is presented by Hungary $-5 \%$, Slovenia, Cyprus, Russia, Italy $-4 \%$ each, Canada, Great Britain and Romania $-1 \%$ each.

Domestic manufacturers offer generic drugs at the pharmaceutical market of Ukraine: tablets $-35 \%$, syrups $-6 \%$, capsules $-4 \%$, drops $-3 \%$, powders, ointments and creams $-1 \%$ each.

Tablets of domestic production are represented by the following trade names: "AcyclovirASTRAFARM" (LLC “ASTRAFARM"), "Acyclovir-FARMAK" (PJSC "Pharmak"), "Acyclovir-Darnitsa" (JSC "Pharmaceutical company "Darnitsa"), "Acyclovir" (PJSC "LekhimKharkiv"), "Herpevir ${ }^{\circledR} "$ (PJSC “Kievmedpreparat"), "Valavir ${ }^{\circledR}$ (PJSC "Pharmak"), "Valtrovir $^{\circledR} "$ (PJSC “Kievmedpreparat”), “Gropivirin” (PJSC “Pharmak”), "Novirin” (JSC “Kiev Vitamin Plant”), "Groprim" (LLC “ASTRAFARM"), “Amiksin ${ }^{\circledR}$ IC” (Additional Liability Company “INTERCHEM”), “Amizon" ${ }^{\circledR}$ (JSC “Farmak”), “Erebra ${ }^{\circledR}$ ” (JSC “Technologist”).

$6 \%$ are syrups: "Neoprinosin" (LLC "DKP "Pharmaceutical Factory"), "Novirin” (JSC “Kiev Vitamin Plant"), "Flavozid ${ }^{\circledR}$ " (PJSC “Pharmak"). The following position is occupied by capsules (4\%): "Nuclex" (LLC "Pharma Start"). 3 \% are drops: "Proteflazid" (LLC "NVK "Ecopharm").

The domestic drugs in the form of powders are represented by the preparations: "Herpevir ${ }^{\circledR}$ " (PJSC "Kievmedpreparat"). The range of soft dosage drugs are presented in the form of ointment ("Herpevir ${ }^{\mathbb{B} " ~(P J S C ~ “ K i e v m e d p r e p a r a t ”) ~ a n d ~ c r e a m ~(“ A g e r p ” ~(J o i n t ~ U k r a i n i a n-S p a n i s h ~ c o m p a-~}$ ny "SperkoUkraine").

According to the results of the analysis of the assortment of foreign drugs by the tablets forms make $35 \%$, creams and syrups $-5 \%$ each, powders $-2 \%$, lyophilisate for the manufacture of solutions for infusions and syrups $-1 \%$ each.

The range of foreign drugs in the form of tablets for the treatment of herpes viral diseases is represented by the following trade names: "Zovirax" (GlaxoSmithKlein Pharmaceuticals SA, Poland), "Acyk ${ }^{\circledR}$ " (Salutas Pharma GmbH, Germany), "Acyclovir stada" ${ }^{\circledR}$ " (STADA Artzneimtitel AG, Germany), "Virolex" (KRKA, d.d., Novo mesto, Slovenia), "Geviran" (POLFARMA SA, Poland), "Medovir" (Medokemi LTD, Cyprus), "Valtsik" (Pharmaceuticals Inc., Canada), "Valtrex ${ }^{\mathrm{TM} "}$ (GlaxoSmithKlein Pharmaceuticals SA, Poland), "Groprinosin ${ }^{\circledR} "$ (LLC “Gedeon Richter Poland”, Poland), "Izoprynozyn” (BP Teva Pharmaceutical Factory, Hungary), "Normomed" (JSC "Obninsk chemical and pharmaceutical company", Russian Federation).

The next position after tablets is occupied by creams and syrups (5\% each). The following trade names are presented in cream form: "Acyk ${ }^{\circledR ”}$ (Salutas Pharma GmbH, Germany), "Virolex" (KRKA, d.d., Novo mesto, Slovenia), "Zovirax"TM" (Glaxo Operations UK Limited, Great Britain), "Acyclostad ${ }^{\circledR}$ (STADA Artzneimtitel AG, Germany). Syrups are represented by the following trade names: "Groprinosin ${ }^{\circledR}$-Richter" (Gideon Richter Romania A.T., Romania), "Neoprinosin” (LLC “Aflopharm Pharmacy Polish”, Poland), "Normomed" (ABC Pharmacieutic SP, Italy).

Powders (2\%) are represented by the following preparations: "Virolex" (KRKA, d.d., Novo mesto, Slovenia), "Medovir" (Medokemi LTD, Cyprus). Also available at the pharmaceutical market of Ukraine are lyophilisate for the manufacture of infusion solutions "Zovirax "TM" (GlaxoSmithKlein Manufacturing SPA, Italy) and syrups - "Groprinosin ${ }^{\circledR}$-Richter" (Gideon Richter Romania A.T., Romania), "Neoprinosin" (LLC “Aflopharm Pharmacy Polish", Poland), "Normomed" (ABC Pharmacheutici SPA, Italy).

The results of marketing research show that $94 \%$ of drugs are monocomponents (Fig. 3).

Based on consideration of combinations of active substances of investigated drugs for the treatment of herpes viral diseases, it is noted that the combined drugs make up a small amount $(6 \%)$ and are all of domestic production: "Flavozid ${ }^{\circledR} "$ (PJSC "Pharmak"), "Proteflazid $^{\circledR}$ (LLC “NVK “Ecopharm”).

According to the results of the study, a macrocontour of the pharmaceutical market segment of drugs for the treatment of herpes viral diseases was constructed (Fig. 4). 


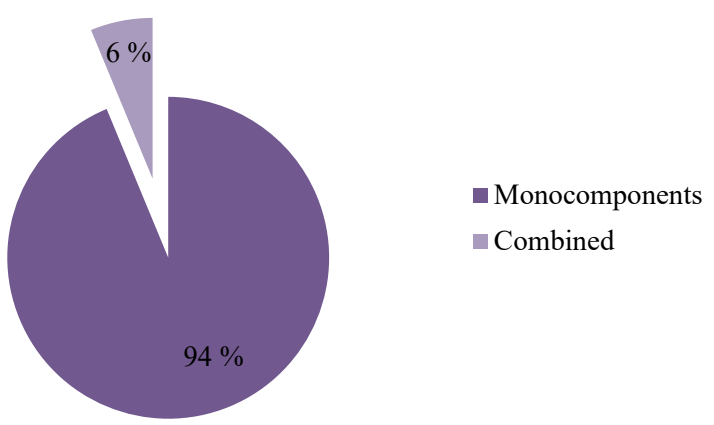

Fig. 3. Analysis of the range of drugs for the treatment of herpes viral diseases by the combination of active substances

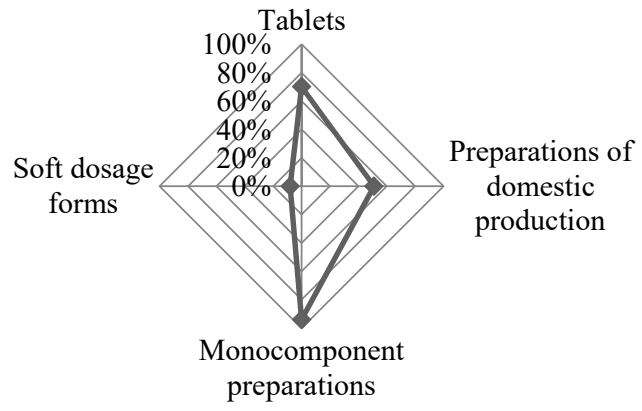

Fig. 4. Macrocontour of the pharmaceutical market segment of drugs used to the treatment of herpes viral diseases

According to the results of the studies it was found that the most common dosage form in the treatment of herpes viral diseases are tablets $(70 \%) ; 51 \%$ of the drugs of this group are produced by the Ukrainian industry. Analyzing the range of drugs used for the treatment of herpes viral diseases by the composition of active substances, it was found that the largest share is in monocomponent preparations $(94 \%)$. Medicines in the soft dosage forms make up only $8 \%$.

\section{Discussion}

Methods for preventing and treating diseases caused by viruses include the following approaches: synthetic drug therapy, immunotherapy, and a combination of these two methods. Given that the major in the treatment of viral diseases are the suppression of virus replication and the restoration of the immune response, the most appropriate to achieve the maximum therapeutic effect is the creation of drugs with different pharmacological actions, in particular combined [10]. One of the most acceptable and convenient to use are the soft dosage forms, as they provide a direct effect on the pathogens, reduce the symptoms of the disease (pain, inflammation, swelling), have a low risk of side effects compared with parenteral and oral drugs.

In scientific works $[17,21]$ organizational, economic and pharmacoeconomic aspects of providing herpes virus patients are covered. The conducted marketing analysis of drugs used for the treatment of herpes viral diseases at the pharmaceutical market of Ukraine complements and deepens previously conducted studies of this problem in Ukraine.

Study limitations. Study limitation were antibacterial drugs and immunomodulators, which can be administered in comorbidities, and it will be our further studies.

Prospects for further research. Prospects for our further research will focus on determining the level of socio-economic availability of this group of medicines for patients and ATC/DDD analysis, by which it is possible to determine the drug consumption of the above group.

The results of the research can be useful for doctors, pharmacists, teachers of medical and pharmaceutical institutions. 


\section{Conclusions}

Marketing analysis of medicines used to the treatment of herpes viral diseases at the pharmaceutical market of Ukraine showed that the range of medicines is limited ( 80 trade names). The main part of the market consist of tablets $(70 \%)$. The largest number of medicines $(51 \%)$ is producted by domestic manufacturers. The leaders among the analysed drugs in the composition of active substances are monocomponent drugs (94\%). The share of the soft dosage forms is only $8 \%$ (“Gerpevir ${ }^{\circledR ”}$ (PJSC “Kievmedpreparat”), “Agerp” (Joint Ukrainian-Spanish company "SperkoUkraine”), "Acyk ${ }^{\circledR}$ (Salutas Pharma GmbH, Germany), "Virolex" (KRKA, d.d., Novo mesto, Slovenia), "Zovirax ${ }^{\mathrm{TM} "}$ (Glaxo Operations UK Limited, Great Britain), "Acyclostad ${ }^{\mathbb{R} "}$ (STADA Artnimnittel AG, Germany).

\section{Conflict of interest}

The authors declare there is no conflict of interest.

\section{References}

[1] Ruderfer, D., Krilov, L. R. (2015). Herpes Simplex Viruses 1 and 2. Pediatrics in Review, 36 (2), 86-90. doi: http://doi.org/ 10.1542/pir.36-2-86

[2] Kinchington, P. R., Leger, A. J. S., Guedon, J.-M. G., Hendricks, R. L. (2012). Herpes simplex virus and varicella zoster virus, the house guests who never leave. Herpesviridae, 3 (1), 1-13. doi: http://doi.org/10.1186/2042-4280-3-5

[3] Mustafa, M., Illzam, E., Muniandy, R., Sharifah, A., Nang, M., Ramesh, B. (2016). Herpes simplex virus infections, Pathophysiology and Management. IOSR Journal of Dental and Medical Sciences, 15 (7), 85-91. doi: http://doi.org/10.9790/0853150738591

[4] Suzich, J. B., Cliffe, A. R. (2018). Strength in diversity: Understanding the pathways to herpes simplex virus reactivation. Virology, 522, 81-91. doi: http://doi.org/10.1016/j.virol.2018.07.011

[5] El Hayderi, L., Delvenne, P., Rompen, E., Senterre, J. M., Nikkels, A. F. (2013). Herpes simplex virus reactivation and dental procedures. Clinical Oral Investigations, 17 (8), 1961-1964. doi: http://doi.org/10.1007/s00784-013-0986-3

[6] Williams, E. J., Embleton, N. D., Clark, J. E., Bythell, M., Ward Platt, M. P., Berrington, J. E. (2013). Viral Infections: Contributions to Late Fetal Death, Stillbirth, and Infant Death. The Journal of Pediatrics, 163 (2), 424-428. doi: http://doi.org/10.1016/ j.jpeds.2013.02.004

[7] Egan, K. P., Wu, S., Wigdahl, B., Jennings, S. R. (2013). Immunological control of herpes simplex virus infections. Journal of NeuroVirology, 19 (4), 328-345. doi: http://doi.org/10.1007/s13365-013-0189-3

[8] Stephenson-Famy, A., Gardella, C. (2014). Herpes Simplex Virus Infection During Pregnancy. Obstetrics and Gynecology Clinics of North America, 41 (4), 601-614. doi: http://doi.org/10.1016/j.ogc.2014.08.006

[9] Torres, L., Ortiz, T., Tang, Q. (2015). Enhancement of Herpes Simplex Virus (HSV) Infection by Seminal Plasma and Semen Amyloids Implicates a New Target for the Prevention of HSV Infection. Viruses, 7 (4), 2057-2073. doi: http://doi.org/10.3390/ v7042057

[10] Roizman, B., Whitley, R. J. (2013). An Inquiry into the Molecular Basis of HSV Latency and Reactivation. Annual Review of Microbiology, 67 (1), 355-374. doi: http://doi.org/10.1146/annurev-micro-092412-155654

[11] Piret, J., Boivin, G. (2010). Resistance of Herpes Simplex Viruses to Nucleoside Analogues: Mechanisms, Prevalence, and Management. Antimicrobial Agents and Chemotherapy, 55 (2), 459-472. doi: http://doi.org/10.1128/aac.00615-10

[12] Bhalekar, M., Upadhaya, P., Reddy, S., Kshirsagar, S., Madgulkar, A. (2014). Formulation and evaluation of acyclovir nanosuspension for enhancement of oral bioavailability. Asian Journal of Pharmaceutics, 8 (2), 110-118. doi: http://doi.org/ 10.4103/0973-8398.134942

[13] Kawamura, K., Hayakawa, J., Akahoshi, Y., Harada, N., Nakano, H., Kameda, K. et. al. (2015). Low-dose acyclovir prophylaxis for the prevention of herpes simplex virus and varicella zoster virus diseases after autologous hematopoietic stem cell transplantation. International Journal of Hematology, 102 (2), 230-237. doi: http://doi.org/10.1007/s12185-015$1810-4$

[14] Popova, O. I. (2013). Herpetychna infektsiia yak providna medyko-sotsialna problema. Sovremennaia stomatolohyia, $2,48-50$.

[15] Bardova, E. A. (2011). Gerpeticheskaia infektsiia: patogenez, klinika, lechenie. Medix Anti - Agent, 2 (20), 44-50.

[16] Kennedy, P. G. E., Rovnak, J., Badani, H., Cohrs, R. J. (2015). A comparison of herpes simplex virus type 1 and varicella-zoster virus latency and reactivation. Journal of General Virology, 96 (7), 1581-1602. doi: http://doi.org/10.1099/vir.0.000128 
[17] Levachkova, Yu. V., Yarnykh, T. G., Litvinova, O. M. (2014). Antiviras today and the prospects of development in Ukraine. Ukrainian biopharmaceutical journal, 6 (35), 18-22.

[18] Aslanyan, M., Bobrytska, L., Hrytsenko, V., Shpychak, O., Popova, N., Germanyuk, T. et. al. (2017). Technological aspects of development of a new drug in tablets called «Lavaflam» and its pharmacoeconomic evaluation. Research Journal of Pharmaceutical, Biological and Chemical Sciences, 4 (8), 808-814.

[19] Looker, K. J., Magaret, A. S., May, M. T., Turner, K. M. E., Vickerman, P., Gottlieb, S. L., Newman, L. M. (2015). Global and Regional Estimates of Prevalent and Incident Herpes Simplex Virus Type 1 Infections in 2012. PLOS ONE, 10 (10), 1-10. doi: http://doi.org/10.1371/journal.pone.0140765

[20] Kovalenko, V. N. (Ed.) (2015). Kompendium 2015 - lekarstvennye preparaty. Kyiv: Morion, 2320.

[21] Bobrytska, L. O., Ruban, O. A., Puliaiev, D. S. (2012). Osoblyvosti perebihu ta aspekty farmakoterapii herpesvirusnoi infektsii. Zbiórraportównaukowych. «Postępy w nauce w ostatnichlatach. Nowychrozwiązań», 9, 29-31.

Received date 05.03.2020

Accepted date 11.05.2020

Published date 31.05.2020
(C) The Author(s) 2020

This is an open access article under the CC BY license (http://creativecommons.org/licenses/by/4.0). 